\title{
COMPARISON OF ANALYSIS AND THE NUTRITIONAL VALUE OF FRESH COMMON CARP, FROZEN AND SOUTHERN CANNED TUNA
}

\author{
Ali Aberoumand, Afsaneh Fazeli
}

\begin{abstract}
Freezing and canning are suitable methods to delay the spoilage of marine products and improve their physico-chemical and organoleptic properties. The fish were transported to the ice in proportion to 1 to $3(\mathrm{w} / \mathrm{w})$ inside the boxes, and then moved wastes. The purpose of this project is to analyse and to compare the nutritional value of fresh, frozen the fish and canned tuna fish. Nutrient composition and $\mathrm{pH}$ of the fresh fish fillet and moisture and ash contents and other nutrient composition were measured by the standard AOAC method. The results showed that the percentage of frozen fish protein was 17.41 and the highest moisture percentage for frozen fish with 72.23. The level of energy (kcal) of canned fish with $393.36 \mathrm{kcal}$ was the highest level. The $\mathrm{pH}$ of the canned fish with 7.28 was the highest $\mathrm{pH}$. The percentage of drip and WHC in frozen fillet found 6.7\% and 6\% respectively. From the obtained results, it can be concluded that despite the low amounts of protein and ash in canned fish, the fat and energy content was the highest. The protein content of the fish is frozen, and its $\mathrm{pH}$ indicates that it was better than fresh fish from point of quality.
\end{abstract}

Keywords: fresh fish; frozen fish; canned tuna fish; nutritional value

\section{INTRODUCTION}

Today's economic considerations have led to the use of affordable, high-value food for the production of canned fish from affordably priced fish. On the other hand, the sharp reduction led to the use of some new types of low consumption in canning. In this study, the measurement of protein, fat, and ash in common carp was investigated. Tuna fishes include several large and red fish from the Scombridae fish family. Unlike other types of fish that have white meat, the tuna fish have pink or dark red meat. In their meat, the amount of myoglobin found in the tissues of the muscle. Tuna meat has a lot of protein and vitamins. Most tuna fish live in the warm sea; the blue wings are about 3 inches long. Albacore is another type of tuna fish. The purpose of this project is to analyse and comparison the nutritional value of fresh carp, frozen carp and canned tuna fish. Although frozen storage is a valuable method of preservation, but the quality of fish is still decreased, and some physic-chemical changes of protein occur such as the changes of muscle texture and flavour loss which is liable to cause consumer rejection. Fish quality depends on safety, nutritional quality, availability, convenience and integrity, freshness, eating quality and the obvious physical attributes of the species, size and product type (Kharestan et al., 2006; Rezaee, 2004; Razai et al., 2004; Rezavi, 2007; Ghanbari et al., 1988; Nasrallah and Novirian, 2012; Yeganeh et al., 2011; Abbas et al.,
2008; Nga, 2010). The purpose of this project is to analyse and compare the nutritional value of fresh, frozen and canned tuna fish.

\section{Scientific hypothesis}

Nutritive quality of fresh, frozen and canned fish is different.

\section{MATERIAL AND METHODOLOGY}

This research was conducted in the fall of 2018 at the Laboratory of Fisheries. The fish purchased from the fish market of Behbahan, known as the common carp, Cyprinus carpio. The fresh fish were transferred to the Fisheries Laboratory of Khatam-al-Anbia University of Technology in Behbahan, in the form of plastic in plastic. Part of fresh fish is placed in a freezer at $-18{ }^{\circ} \mathrm{C}$ to freeze. The fresh and frozen fish are filleted after thawing for the tests, such as nutrient composition and $\mathrm{pH}$ of the fresh fish fillet. The moisture content and amount of ash and other compounds and nutritional and qualitative indices were measured by the standard AOAC (2005) methods.

\section{Moisture measurement method}

The moisture content of fresh fillet was determined by drying part of the sample for $24 \mathrm{~h}$ and expressed as percentage and was measured with constant weight. 
Various types of moisture measurements were used, such as electric ovens, desiccators that contain a humidifier, laboratory scale, thin metallic dishes with a diameter of at least $60 \mathrm{~mm}$, a height of $25 \mathrm{~mm}$, and special containers for measuring moisture. We cooled the dictator in the laboratory temperature. 5 to $10 \mathrm{~g}$ of the sample was placed to the container. After $6 \mathrm{~h}$, container was removed from the oven, then it was weighing exactly after cooling in the desiccators. And again, we put it back to the oven, after one day, so the weighing operation was repeated in the way mentioned, if the two obtained weight differ, then this must be repeated until we take a constant weight.

\section{Determination of ash}

We use dry method to measure ash. To this purpose, we place $5 \mathrm{~g}$ of the sample in a Chinese plant. Heat in a furnace was $500-550{ }^{\circ} \mathrm{C}$ until we obtained a bright grey colour. And in the end what remained as the ash is calculated by AOAC (2005).

\section{Fat Measurement}

Total fat was measured by Soxhlet method. For this purpose, $5 \mathrm{~g}$ of homogenized sample was placed in a dish and heated in $35 \mathrm{CC} \mathrm{HCl}$ with distilled water. The fat sample obtained by the solvent ether was extracted using a Soxhlet apparatus. The remaining solvent was evaporated. After drying, the balloon weight was determined until it reached the constant weight. The difference between initial and final weight shows fat content as a percentage AOAC (2005).

\section{Raw Protein Measurement}

Measurement protein was performed using the using the kjeldahl method. For this purpose, $5 \mathrm{~g}$ of homogeneous fillet with $20 \mathrm{~mL}$ of concentrated sulfuric acid and $8 \mathrm{~g}$ of catalysts were placed in a special dish, and then $30 \mathrm{~min}$ at $350{ }^{\circ} \mathrm{C}$ heated. After digestion, the sample was transferred automatically to $\mathrm{NaOH}$ solution, $32 \%$. The distillation vapours were transferred in a container containing boric acid $2 \%$ and a few drops of the reagent. Then by $\mathrm{HCl}$ normal titrated AOAC (2005).

\section{PH measurement}

The $\mathrm{pH}$ of the fresh fillet was measured using a digital $\mathrm{pH}$ meter of the Parta bell of the pcd650 model. Preparation of the samples was carried out to measure the $\mathrm{pH}$, based on the standard method, and based on this method, $10 \mathrm{~g}$ of homogeneous fish fillet in $100 \mathrm{~mL}$ of water was mixed. The $\mathrm{pH}$ was measured using $\mathrm{pH}$ meter.

\section{Tuna fish}

Canned fish were purchased from the southern fish canning factory, its production date was 12.1.2008 and its expiry date is 12.1.2009.

\section{Tuna fish moisture analysis}

Moisture was carried out by drying. For this purpose, $5 \mathrm{~g}$ of homogeneous samples were placed in a petri dish, dried for $16 \mathrm{~h}$ in a temperature of $100{ }^{\circ} \mathrm{C}$ to $120^{\circ} \mathrm{C}$ in reached a constant weight. The sample percentage of moisture content was considered AOAC (2005).
The energy content of the canned fillet was calculated by Scholes method.

\section{Methods of measuring the water drop and WHC}

The water holding capacity was measured using a method by Rørå et al. (2003), using centrifugation. $2 \mathrm{~g}$ of fish were weighed and placed in a centrifuge tube with Maidstone, Whatman England paper (V1). The centrifugation was carried out at $4000 \mathrm{rpm}$ for $10 \mathrm{~min}$ at $10^{\circ} \mathrm{C}$ and the wet filter paper (V2) was weighed to $50{ }^{\circ} \mathrm{C}$ before reaching constant weight (V3). The following formula were used to calculate the WHC:

$$
\text { Water holding capacity }=(\mathrm{V} 2-\mathrm{V} 3) / \mathrm{S} \times 100
$$

Where: S represents the sample weight of the fish.

For determination of drop water, before and after thawing, sample weighted and after thawing water extracted from fillet. The following formula were used to calculate the water drop content:

Water drop $=$ before thawed sample weight - after thawed sample weight / before thawed sample weight $\times 100$

\section{Statistical analysis}

Data analysis was done in three replications. The Duncan's mean comparison test was used at 5\% level. The calculations were performed using SPSS 19 software (IBM, USA). Results were expressed as mean of triplicate trials. Data were analysed by one-way analysis of variance on the means of values $(p<0.05)$.

\section{RESULTS AND DISCUSSION}

The results showed that the percentage of protein in fresh fish was higher than the canned fish protein. Another study on lipid levels showed that fat content in fish increased with pass time. The $\mathrm{pH}$ of the canned fish was the same as the frozen. It decreased with increasing time after processing and does not follow a particular trend. The amount of ash in canned fish was less. Increasing the amounts of fat during the storage period in two types of canned fish compared to the fresh fat content in this study agreed with the results of Greenfield and Kosulwat (1991).

In the present study, there was a positive and significant correlation between $\mathrm{pH}$ and fluid drop in most of the maintenance days and found that there was generally a reverse relationship between drop and muscle $\mathrm{pH}$. Such a model might be able to observe for the initial hours of fishing, but during the maintenance period other than $\mathrm{pH}$, other factors also have an impact on the amount of water checked. Hence, it seems that the difference in WHC can be attributed to the difference in the degradation of the autolysis or microbial for structure of the muscle. Increasing the maintenance days increased the distance between cells in muscle fibers, and muscle water holding capacity decreased. The results showed that the protein content of fresh fish was higher than the canned fish protein. 


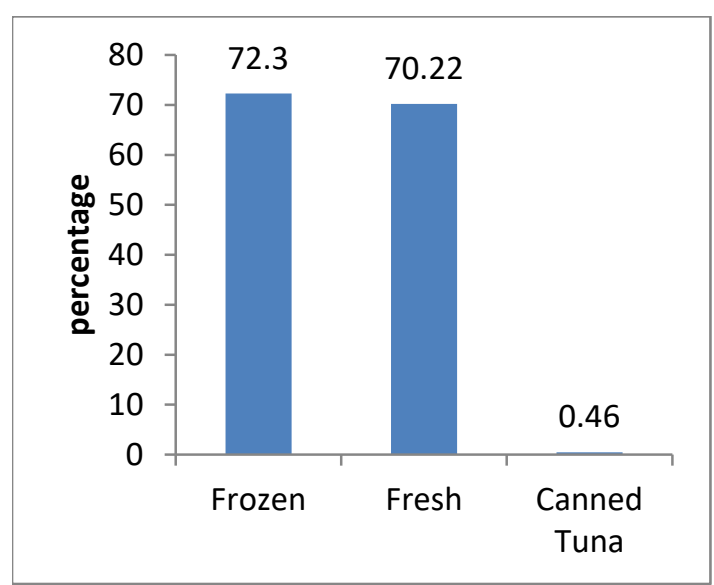

Figure 1 Comparison of moisture contents of fresh fish with frozen and canned fish tuna.

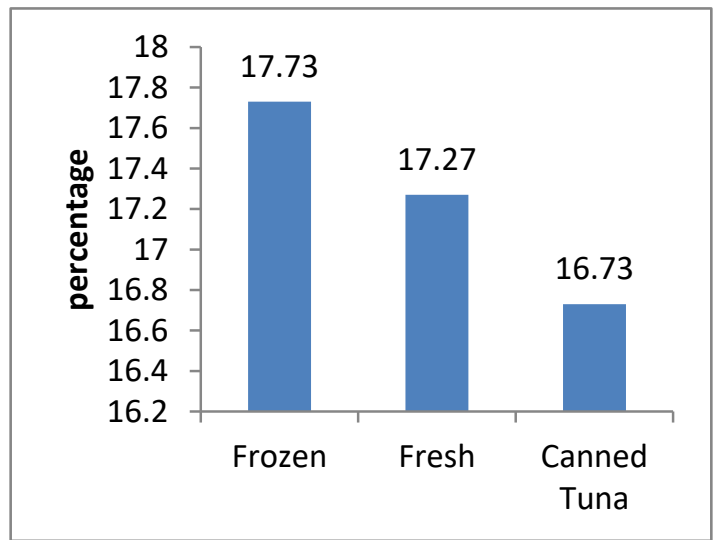

Figure 3 Comparison of protein contents of fresh fish with frozen canned fish tuna.

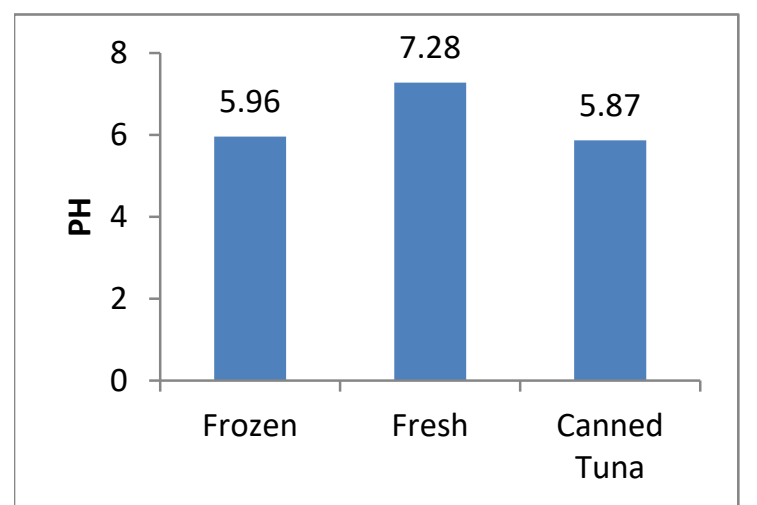

Figure 5 Comparison the $\mathrm{pH}$ of fresh fish with frozen frozen and canned tuna.

The fat content of fresh fish was less than the canned fish. Because oil can be added to cans. The fat content of the fresh fillet was higher than the frozen fillet. The amount of ash of fresh fillet with frozen didn't differ. But it was more than canned fish ash. The moisture content of fresh fish was higher than that of frozen fish and was much higher than that of canned fish. The energy in $\mathrm{kcal} / \mathrm{g}$ of canned fish was more than fresh fillets and frozen fillets, respectively. The reason was that the amount of fat in canned fish was much larger than the other two samples. The energy content of the frozen fillet was the smallest, since some water along fat was removed by thawing.

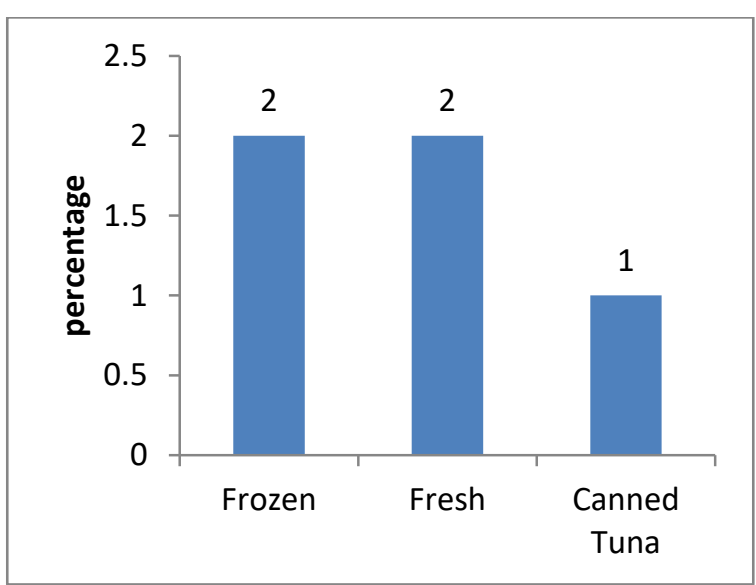

Figure 2 Comparison of ash contents in fresh fish with frozen and canned fish tuna.

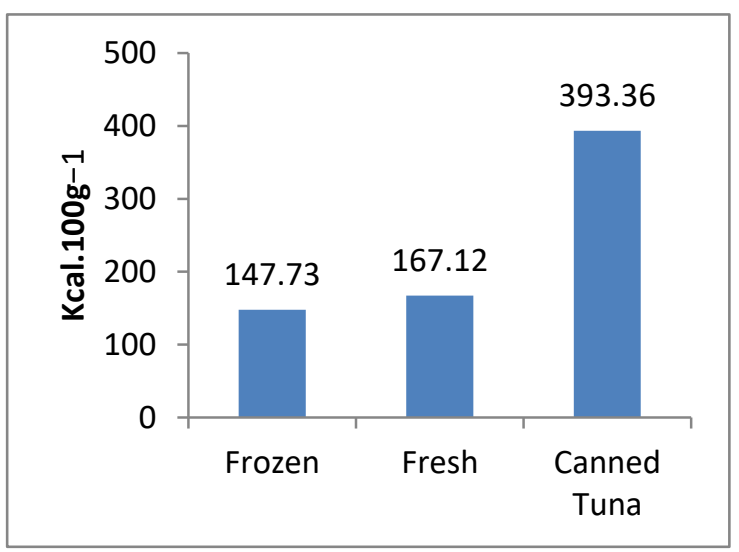

Figure 4 Comparison of energy value (kcal) in fresh and frozen fish fillet with canned fish tuna.

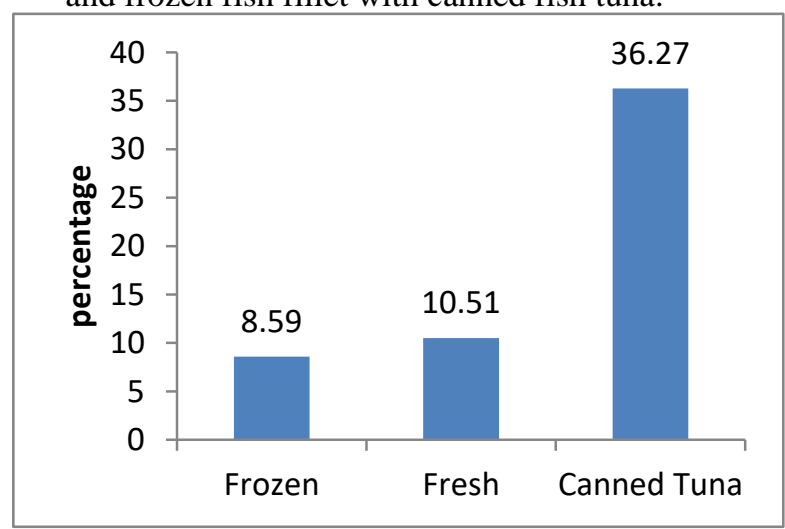

Figure 6 Comparison of fat percentage in fresh fish with frozen and canned tuna

An efficient method for showing qualitative changes in fish meat, was calculating fish muscle water holding capacity that show the study of changes in its microstructures during storage. Ability to keep water was considered as one of the important parameters in the quality. Because WHC for the consumer and for industry was important. the reduction of muscle WHC was often as a result of a structural changes in the muscle, which occurs after fish death. Study of the trend of spoilage in tropical fish can provide useful information on the reduction of spoilage, handle and fish distribution in the area. There is little information about the changes in muscle fibers and its relation to the water holding capacity in the fishes of 
Gulf of Persian Gulf and Oman Sea. The study was to investigate the changes in fish muscle tissue microstructures and their association with muscle water holding capacity of 14 days in a refrigerator (Olsson, Seppola and Olsen, 2007).

The percentage of WHC in frozen fillets was $6 \%$ and the percentage of drop in frozen fillets was $4.7 \%$. The percentage of fresh fillet fat in this study was $10.51 \%$, which was lower than the fresh fat content in the fresh fillet in another fish $(11.31 \%)$. The protein percentage of the fresh fillet was $17.27 \%$, which high compared with the protein percentage of the other sample $(3.96 \%)$. So, there is a lot of significant difference $(p<0.05)$. The fresh fillet moisture content of this study was $70.22 \%$, which was compared with the moisture content of the fresh fillet $(81.9 \%)$ and the difference was not significant $(p<0.05)$. The $\mathrm{pH}$ of the fresh fillet of this study was 5.87, which was compared with the $\mathrm{pH}$ of the freshly prepared fresh fillet (7.3) in another sample, which showed a significant difference between them $(p<0.05)$. The percentage of fat in the frozen fillet of this study $(8.39 \%)$, which was compared with the percentage of frozen fillet fat of the other sample, was $12.96 \%$. different was significant $(p<0.05)$. The percentage of moisture in the frozen fillet was $71.23 \%$, which was compared to $73.3 \%$ of the frozen fillet in another sample. There was little difference $(p<0.05)$. The percentage of protein in the frozen fillet was $17.41 \%$ but in frozen fillet protein in another sample was $67.74 \%$. Tuna fat content in this study was $36.27 \%$, compared to the other fish $39.3 \%$, which is not significantly different $(p<0.05)$. The percentage of ash of tuna was $1 \%$ compared to $2 \%$ of the other fish. The energetic value percentage of tuna in this study was $36.339 \mathrm{kcal}$, compared with a different sample of tuna fish (369.11) $(p<0.05)$.

The major component of fish was moisture. From the maximum moisture content in were observed in Cyprinus carpio (78.51\%), Hantoush et al. (2015), that found more than present study result (70\%), also according to results of Hantoush et al. (2015) the lipid content in the muscles of Cyprinus carpio was (3.16\%), and protein value was in Cyprinus carpio (14.74\%), but protein and fat values in present study found more than this. The low values of fat in the fillet of these species could be due to the high metabolism required for spawning (Osibona, Kusemiju and Akande, 2006). The high muscles protein contents may be from the equally high protein content of their diets (Osibona, Kusemiju and Akande, 2006). The moisture, protein, fat, ash content of fresh common carp mince was found to be $77.84 \%, 16.95 \%, 3.15 \%$ and $1.17 \%$, respectively Bavitha (2015), compared to present study showed that showed except moisture content, proximate composition contents in present study found more than Bavitha (2015), results. Comparison between moisture and fat content in Bighead Carp showed a correlation between the results which correlate well with the expected inverse ratio between water and lipid matter as it had been previously described (Aubourg et al., 2005). Increasing in water content may increase the rate of lipid hydrolysis, thus reduce the fat content (Latip, Zzaman and Yang, 2013). Siddique et al. (2011) observed decreasing in total lipid content while assessing the effect of freezing time on nutritional value of Puntius sophore, $P$. saranaand $P$. gonionotus during the frozen storage at $-5{ }^{\circ} \mathrm{C}$ of 20 days. This was due to both lipid oxidation and hydrolysis had taken place during ice and cold storage Latip, Zzaman and Yang, 2013). The protein content in Bighead Carp showed a significant decrease $(p<0.05)$ throughout chilled-frozen storage (Latip, Zzaman and Yang, 2013). During investigation decreasing trend was found in fillet of Mystus seenghala in frozen samples (Gandotra et al., 2012). This decrease was rapid and higher in fresh stored at $-10{ }^{\circ} \mathrm{C}$ compared with those stored at $-30{ }^{\circ} \mathrm{C}$. The decrease in protein solubility could be due to protein denatured and protein aggregation induced by frozen storage. The stabilization of myofibrillar proteins is directly related to better fish quality (Martinez, Friis and Careche, 2001). Thus, the decreasing in protein content showed that there was a decreasing in fish quality during frozen storage (Latip, Zzaman and Yang, 2013), that not agreed with present study. During chilled-frozen storage, the ash content in Bighead Carp showed a significant decrease (Latip, Zzaman and Yang, 2013), which not agreed with present study results, this different duo to the location and environmental conditions of the fish and the method of analysis and type of apparatus. Canning process, including the addition of filling materials, that to affect the macronutrient contents of the canned product compared with that of the raw ones (Herawati, Susanto and Kurniadi, 2016). This effect was found in this study in terms of moisture (decreased) and fat (increased) contents (Bahurmiz, Al-Sa'ady and Adzitey, 2018), this is agreed with present study.

\section{CONCLUSION}

This research was conducted on the nutrients of fresh fish of common carp and frozen fish and canned tuna fish in the southern Iran. The results obtained showed the percentage of canned fat $(36.27 \%)$ that was the highest percentage. The ash amounts of frozen and fresh with $2 \%$ found higher than ash in canned fish with $1 \%$. The percentage of protein in frozen fish was the highest and the highest percentage for moisture found for frozen fish. The except moisture content, proximate composition contents of carp fresh fish in present study found more than Bavitha (2015) results. The level of energy (kcal) of canned fish was the highest. The $\mathrm{pH}$ of canned fish was the highest $\mathrm{pH}$. The percentage of drop in frozen fillets was $6.7 \%$. WHC level was 6\%. This effect canning was found in this study for moisture content decreased and for fat value increased that compared with frozen and fresh fishes, was agreed with other authors. It can be concluded that despite the low level of protein and ash in canned fish, the highest fat and energy was obtained. The protein content of the frozen and its $\mathrm{pH}$ indicates that it was better than fresh fish in terms of quality.

\section{REFERENCES}

Abbas, K. A., Mohamed, A., Jamilah, B., Ebrahimian, M. 2008. A review on correlations between fish freshness and $\mathrm{pH}$ during cold storage. American Journal of Biochemistry Biotechnology, vol. 4, no. 4, p. 416-421. https://doi.org/10.3844/ajbbsp.2008.416.421

AOAC. 2005. Association of Official Analytical Chemists. Official Methods of Analysis. $16^{\text {th }}$ ed. Arlington, Virginia : AOAC, $1141 \mathrm{p}$. 
Aubourg, S. P., Pineiro, C., Gallardo, J. M., BarrosVelazquez, J. 2005. Biochemical changes and quality chilled storage of farmed turbot (Psetta maxima). Journal of Food Chemistry, vol. 90, no. 3, p. 445-452. https://doi.org/10.1016/j.foodchem.2004.05.008

Bahurmiz, O. M., Al-Sa'ady, M., Adzitey, F. 2018. Nutritional and sensory characteristics of locally produced canned tuna from Hadhramout, Yemen. International Journal of Food Science and Nutrition, vol. 3, no. 5, p. 13-18.

Bavitha, M. 2015. Development Of Value Added Products From Common Carp (Cyprinus Carpio) and its quality evaluation : dissertation theses. Andhra Pradesh, India : Technology Sri Venkateswara Veterinary University, 169 p.

Gandotra, R., Sharma, S., Koul, M., Gupta, S. 2012. Effect of chilling and freezing on fish muscle. Journal Pharmalogy Biology Science, vol. 2, p. 5-9. https://doi.org/10.9790/3008$\underline{0250509}$

Ghanbari, M., Jami, M., Naghdi, M. S., Shahriari, M. M. 1988. Investigating the Long-term Effects of Water and $\mathrm{pH}$ Changes on Blood Indices of Common Carp (Cyprinus Carpio). Journal of Biology, vol. 22, no. 1, p. 145-143.

Greenfield, H., Kosulwat, S. 1991. Nutrient composition of Australian fresh retail sausages and effects of cooking on fat content. Journal of the Science of Food and Agriculture, vol. 57, p. 65-75. https://doi.org/10.1002/jsfa.2740570108

Hantoush, A. A., Al-Hamadany, Q. H., Al-Hassoon, A. S., Al-Ibadi, H. J. 2015. Nutritional value of important commercial fish from Iraqi waters. International Journal of Marine Science, vol. 5, no. 11, p. 1-5.

Herawati, E. R. N., Susanto, A. A., Kurniadi, A. S. 2016. Effect of brine concentration on the nutrient content and fatty acid profile of canned catfish [Pangasius Sutchi (Fowler, 1937)]. Aquatic Procedia. vol. 7, p. 85-91. https://doi.org/10.1016/j.aqpro.2016.07.011

Kharestan, M., Rezaei, M., Ojagh, M., Bobakhani Lashkan, A. 2006. Comparison of nutritional values and omega-3 fatty acids of dorsal and abdominal muscles of common carp (Cyprinus Carpios). Iranian Journal of Marine Science, vol. 3, no. 4, p. 31-37.

Latip, D. N. H., Zzaman, W., Yang, T. 2013. Effect of chilled-frozen storage on the physico-chemical, microbial and sensory quality of farmed Bighead Carp (Hypophthalmichthys nobilis). Journal of Fisheries andAquatic Science, vol. 8, no. 6, p. 686-696. https://doi.org/10.3923/jfas.2013.686.696

Martinez, I., Friis, T. J., Careche, M. 2001. Post mortem muscle protein degradation during ice-storage of Arctic (Pandalus borealis) and tropical (Penaeus japonicas and Penaeus monodon) shrimps: A comparative electrophoretic and immunological study. Journal of Science and Food Agricultural, vol. 81, no. 12, p. 1199-1208. https://doi.org/10.1002/jsfa.931

Nasrallah, Z. A., Novirian, H. 2012. Effect of Different Different Levels of Root Crop (Austratis Phragmitis) as a Growth Supplementary Feed for Young Common Carp (Cyprinus Carpio). Journal of Animal Research, vol. 4, no. 26, p. 1392.
Nga, M. T. T. 2010. Enhancing quality management of fresh fish supply chains through improved logistics and ensured traceability : dissertation theses. Reykjavik : University of Iceland, 88 p. ISBN 978-9979-9928-4-4.

Olsson, G. B., Seppola, M. A., Olsen, R. L. 2007. Waterholding capacity of wild and farmed cod (Gadus morhua) and haddock (Melanogrammus aeglefinus) muscle during ice storage. Lebensm-Wiss-Technology, vol. 40, p. 793-799. https://doi.org/10.1016/j.lwt.2006.04.004

Osibona, A. O., Kusemiju, K., Akande, G. R. 2006. Proximate composition and fatty acids profile of the African Catfish Clarias gariepinus. Acta Satech., vol. 3, no. 1, p. 1-5.

Razai, M., Sahrari, M. A., Moeini, S., Safari, M., Ghaffari, F. 2004. Comparison of fat quality of anchovy fish in two methods of cold storage and handle. Iranian Journal of Fisheries Science, vol. 12, no. 3, p. 97-108.

Rezaee, M. 2004. Effects of Temperature and Cold Storage Time on Changes in Anchovy Kilka Fish Fat : dissertation theses. Tehran, Iran : Tarbiat Modares University.

Rezavi, S. 2007. Marine products Production Technology. $2^{\text {nd }}$ ed. Iran : Pars Negar Publication.

Rørå, A. M. B., Regost, C., Lampe, J. 2003. Liquid holding capacity, texture and fatty acid profile of smoked fillets of Atlantic salmon fed diet containing fish oil or soybean oil. Food Research International, vol. 36, p. 231-260. https://doi.org/10.1016/S0963-9969(02)00141-2

Siddique, M. N., Hasan, M. J., Reza, M. Z., Islam, M. R. Boduruzaman, M., Forhadur, M., Reza, S. 2011. Effect of freezing time on nutritional value of Jatpunti (Puntius sophore), Sarpunti ( $P$. sarana) and Thaisarpunti ( $P$. gonionotus). Bangladesh Research Publication Journal, vol. 5, p. 387-392.

Yeganeh, S. B., Hosseini, E., Impanpour, M., Sha'bani, A. S., Abbasi, M. 2011. Evaluation of Seasonal changes in chemical composition and fatty acids Composition of Cyprinus Carpio. Journal of Biology, vol. 2, no. 25, p. 1391.

\section{Acknowledgments:}

We thank to Dr. Ali Aberoumand, Associate Professor of Faculty of Natural Resources, Behbahan Khatam Alanbia University of Technology, Behbahan, Iran for help with the experimental work.

\section{Contact address:}

*Ali Aberoumand, Behbahan khatam Alanbia University of technology, Department of Fisheries, Behbahan, Iran, No 22, second Alley of Ab va Bargh, Zolfeghari, Behbahan, Khuzestan Province, Iran, Tel.: +989167277178,

E-mail: aberoumandali@yahoo.com ORCID: https://orcid.org/0000-0003-3387-433X

Afsaneh Fazeli, Student, Behbahan khatam Alanbia University of technology, Department of Fisheries, Iran, Email: Afsanehfazeli@yahoo.com

Corresponding author: * 